\title{
The Analysis of Gender Markers in Animals
}

\begin{abstract}
This paper aims to be a contribution to the study of the linguistic concept of gender. Out of many potential challenges in this area, it will focus on the problem of assigning gender to animal nouns. This problem is topical in view of the fact that in present-day English, gender is a marginal grammatical category and therefore recedes into the background in descriptions of today's English. Grammatical gender is a rare topic of research and scientific discussions or papers.

A detailed analysis of gender assignment to animal names is based on two subcorpora (the English edition of National Geographic and the English edition of Journal of Zoology). To make the picture as complete as possible, a contrastive analysis of gender markers is offered.
\end{abstract}

Key words

Gender markers; animal nouns; gender distinctions; comparative analysis; subcorpora

\section{Introduction}

"Gender is the most puzzling of the grammatical categories. It is a topic which interests non-linguists as well as linguists and it becomes more fascinating the more it is investigated."

(Corbett 1991: 1)

To mention just a few works dealing with gender assignment in Modern English, modern views on the existence of the category of gender can be found in Vachek (1964), whose criteria for assigning gender are in agreement with the factors that are identified as crucial in my own analysis. He notes that "the shift of gender" is motivated by affect or emotion (Vachek 1964: 190). A special case is constituted 
by pronominal reference to nouns denoting small children and animals. When the sex of the individual concerned is either unknown or irrelevant (e.g. fly, cat, etc.), neuter reference is commonly used. On the other hand, feminine or masculine reference signals "some interest of the speaker in the individual referred to" (Erades 1956: 7, cited in Vachek), but the gender chosen need not necessarily tally with the actual sex of the individual: "there may be, again, some interference of emotional factors" (Vachek 1964: 191). The author also mentions "some interference of emotive factors" and personifications which may often be effected on traditional, conventional lines. "These conventions can be squared with the tendencies governing pronominal reference to nouns denoting inanimate things: bigger and stronger animals rank most frequently as masculines, while smaller, gentler animals (especially singing birds) prevalently rank as feminines" (Vachek 1964: 191).

Crystal (1995: 209) solves the problem of personification and the reasons for the prevalence of the feminine pronouns in "neuter" contexts. As he notes "Many nouns are given variable gender, depending on whether they are thought of in an intimate way. Pets are often he or she."

Brinton (2000, cited in Wagner 2003: 48) notes that "gender is generally a covert category" in nouns, while "a related category of animacy" is expressed in personal, interrogative and relative pronouns. Very interesting is the animacy grouping. She distinguishes two main groups - humans and higher animals in one group and lower animals and inanimates in the second. Animals thus emerge on both sides of the scale, as can be seen in the following scheme:

Figure 1. Gender categories in Brinton (cited in Wagner 2003: 48)

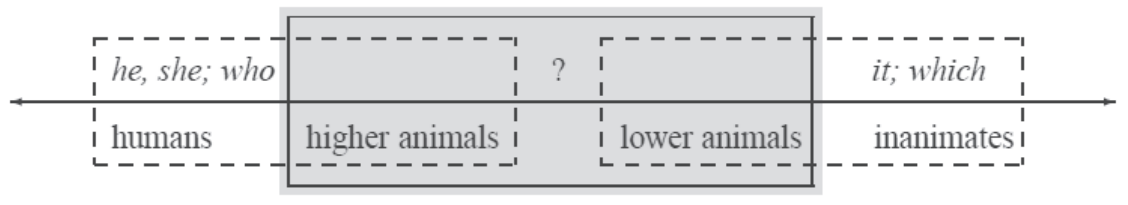

According to this scale it is clear that gender assignment depends on a wide variety of influential factors.

Mackay and Konishi (1980, cited in Wagner 2003: 121) investigated the use of "human" pronouns to refer to non-human antecedents in children's literature. One class contained animals (including real, imaginary, and toy animals). The major result from the counts was highly unexpected $-82 \%$ of pronominal references concerning animals were masculine (62\%), and feminine (20\%), respectively (Wagner 2003: 122).

The gender of animals in modern Canadian English is investigated by Morris in her doctoral thesis (Morris 1991, cited in Wagner 2003). In her data, based on evidence and observations, "animals are much more frequently he than she" (Wagner 2003: 140). The following scheme shows the hierarchical system of assigning gender to animals based on her research (Morris 1991 cited in Wagner 2003: 141): 
Figure 2. Hierarchical system of assigning gender to animals (Morris 1991 cited in Wagner 2003: 141)

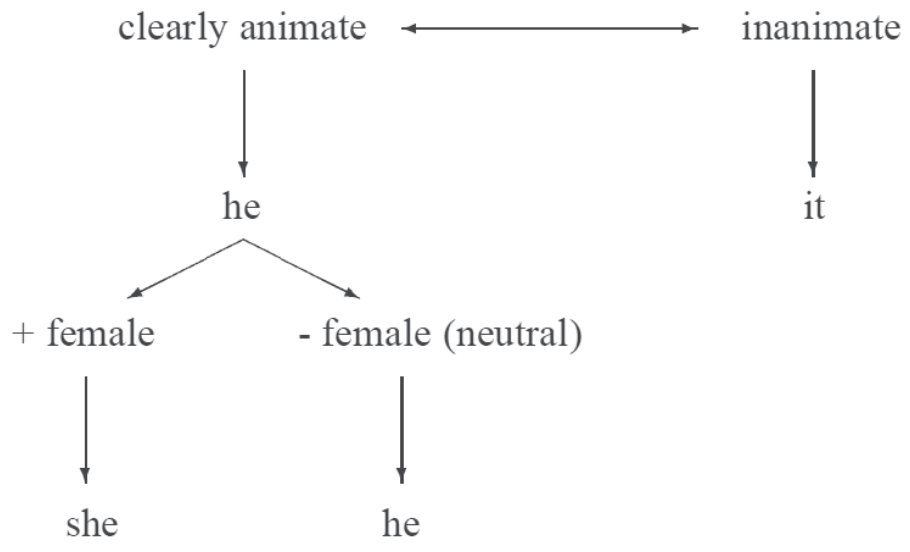

In Marcoux (1973) the students' use of personal pronouns in tag questions was investigated. He found a surprisingly high occurrence of "human" pronouns used to refer to animals of unknown sex. The masculine pronouns prevailed (Marcoux 1973: 104).

A similar research is described in Prčíková's doctoral thesis (Prčíková 1999). The corpus for her analysis includes children's stories published in Britain and the U.S. Seventy nine per cent of observed pronominal pronouns referring to animals were masculine, 10\% feminine (Prčíková 1999: 51).

Although the respective authors base their studies on a variety of different corpora, such as children's literature, web pages devoted to animal keeping and breeding and students' use of personal pronouns in tag questions, the major results of my research are rather unexpected. As all of the authors found a surprisingly high number of "human" pronouns used to refer to animals, they claim that masculine is the prevailing gender. The findings offered by authors can be summarized as follows:

- The choice of pronouns referring to animals is affected by a number of emotive factors and by the degree of personal involvement.

- The cut-off point within the class of animals differs from speaker (or author) to speaker depending on their professions, environment, etc.

- When referring to animal nouns, neuter pronouns are the least frequently occurring forms, while the masculine dominates. 


\section{The comparison of gender markers in animals included in the corpora of National Geographic and Journal of Zoology}

The aim of this analysis is to ascertain the differences in gender assignment in animals in two different sources - the non-fiction literature as represented by National Geographic, and the research zoological papers included in Journal of Zoology.

The analysis has comparedd animal species with masculine and feminine pronouns taken from National Geographic corpus and the same animal species taken from the Journal of Zoology.

Only 16 identical species of animals have been found within the two corpora under study. Their masculine and feminine gender references retrieved from both corpora have been analysed and compared. The following is the list of identical species under study:

- mantis, cricket, spider, crab, turtle, lizard, snake, bat, albatross, seal, wild dog, wolf, fox, lynx, bear and horse.

The analysed animals have been arranged according to the biological classification, starting with the lowest insect and finishing with big mammals.

\subsection{Final charts and material analysis}

Sixteen species taken from Journal of Zoology were referred to by 413 pronouns as follows:

\begin{tabular}{|l|c|c|}
\hline Masculine & 57 & $13.8 \%$ \\
\hline Feminine & 168 & $40.7 \%$ \\
\hline Neuter & 188 & $45.5 \%$ \\
\hline Total & 413 & $100 \%$ \\
\hline
\end{tabular}

Table 1. Pronoun reference in Journal of Zoology

Sixteen species taken from National Geographic were referred to by 752 pronouns as follows:

\begin{tabular}{|l|c|c|}
\hline Masculine & 176 & $23.4 \%$ \\
\hline Feminine & 287 & $38.2 \%$ \\
\hline Neuter & 289 & $38.4 \%$ \\
\hline Total & 752 & $100 \%$ \\
\hline
\end{tabular}

Table 2. Pronoun reference in National Geographic 
Figure 3. Final comparative charts

National Geographic

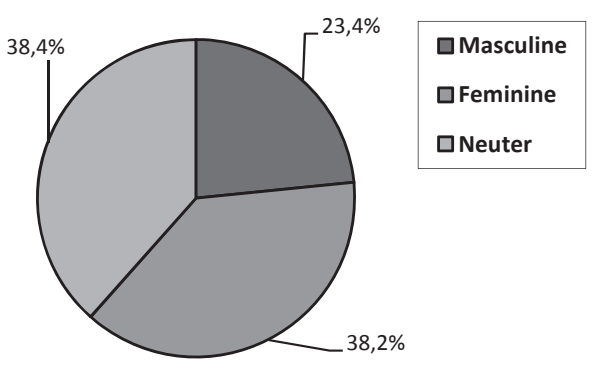

Journal of Zoology

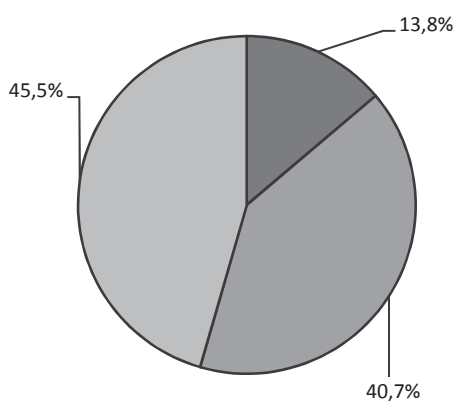

The above comparative analysis includes a wide variety of animal species. All of them contain a surprisingly high number of different gender markers. Although the number of pronouns is higher in National Geographic articles, the percentage of occurrence of all masculine, feminine and neuter gender markers in both sources is, surprisingly, nearly in balance. The most illustrative example is the comparison of the "lowest" animals of this comparative analysis - the insect species, especially the praying mantis. The charts show the same proportions of masculine pronouns and a very similar gender occurrence of feminine and neuter markers. The occurrence of all gender markers was nearly the same in both sources. The main themes of all articles concerning insects were courtship and mating processes. Above all, the reproductive process of the praying mantis is so specific that all the excerpted articles had nearly the same structure and gender references:

(1) As mating proceeds, the female clutches the male around the neck and begins to feed on his head. Though now decapitated, the male has a nervous system that enables him to continue mating. Some scientists have suggested that the male thus benefits his offspring by providing protein for the female during egg production. (National Geographic vol. 165, 1984: 274)

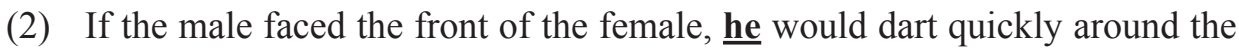
tree trunk and move into position behind her... Once the male's head was within c. $5-10 \mathrm{~mm}$ of the female's abdomen, he would leap onto the female's back, gripping her thorax or midlegs with his forelegs...

(Journal of Zoology vol. 271, 2007: 257)

Different proportions of gender assignment have been found in another researched species of insects - cricket. Although the number of species in both sources was the same, the occurrence of gender markers was noticeably higher in research papers.

Parental care was mostly mentioned in reference to spiders: 
(3) She eats her booty one egg at a time, putting each into her mouth with $\underline{\text { her }}$ palps. .....Portia dropped on her own silk line alongside the web. Then Portia began to swing toward her victim... until she made a kill.

(National Geographic vol. 190, 1996: 114)

(4) This form of maternal 'care', otherwise referred to as 'tolerant' behaviour, comprises passive care behaviours. For example, a mother may protect her young from predators as a passive consequence of her presence, and food items in the form of discarded carcasses that she has previously fed upon may be available for her offspring to pick over...

(Journal of Zoology vol. 271, 2007: 233)

The crab species were referred to as feminine in the majority of examples. Thematically, the articles dealt with reproduction, maternity care, egg laying and nest building. The following examples describe mating in crabs, therefore the animals are viewed as he and she, respectively:

(5) In summer and early fall the female, a "she crab" to watermen, prepares to molt for the very last time. She rocks from side to side, waving her claws. The male, a "jimmy", then cradles her with his walking legs and takes her with him in search of a secluded place out of harm's way. The female backs out of her shell and is ready-for the only time in her life-to mate. (National Geographic July 1992: 114)

(6) ...they may still be controlled by her as the gametes are kept within her shell. When male finds a female, he drags her by grasping her shell using his left minor cheliped. The process, which is that male behaviour intends to exhaust the female, weakening $\underline{\underline{h e r}}$ and thus facilitating $\underline{\text { her }}$ exit from the shell... (Journal of Zoology vol. 270: 596)

The turtle species was a typical example of an animal in a long-term research study which is always assigned to gender. The prevalence of feminine pronouns in Journal of Zoology corpus was caused by the long-term study of the analysed female.

The reptiles also show balanced gender assignment in both sources. It could be explained by the same themes under study, concerning mating and motherhood.

Bat species belong to the most frequently occurring animals in both sources. I have discovered 20 species of this animal in the research papers, nine of them with gender references mostly related to parental care. The majority of the pronouns in both corpora were neuter.

Albatross species with gender assignment taken from National Geographic corpus showed the dominant role of neuter pronouns. The rest of pronouns were feminine, referring to behaviour. Gender assignment was quite different in research papers. The authors referred to males and females as he and she in the descriptions of behaviour, egg laying and nesting : 
(7) In the Falklands a female black-browed albatross yields her throat to her mate's nibbles, and offers a graceful beak-stroke of her own. (National Geographic December 2007: 101)

(8) Females would climb onto the nest and sit if she was not already in this position. The male would then mount her and orient himself so that he was facing the same direction before lowering his body to rest against her back. The male would then lower his head and repeatedly tap his bill against the female's bill, while at the same time extending his tail out behind him and swinging it rapidly from side to side.

(Journal of Zoology vol. 270: 630-631)

Seals belonged to frequently occurring species in both sources. The majority of examples referred to maternal care.

The next group under study was carnivorous mammals. I have found gender distinctions in four species - wild dog, wolf, fox and lynx. The high occurrence of masculine and feminine pronouns could be explained by their life in packs with a specific social structure and hierarchy. The researchers have even named the animals. Thus life in the "family" influences gender markings in all the examples analysed:

(9) We find Blackcomb before the other dogs do, with his nose in the warm belly

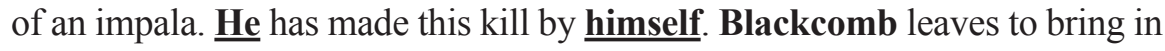

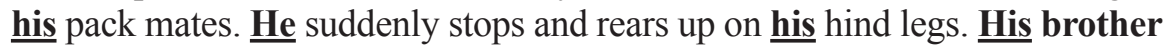
Tremblant joins him. (National Geographic May 1999: 53, 54)

(10) It appeared that Hans did not accept his subordinate position, as he regularly refused to show submission to George. (Journal of Zoology vol. 270: 506)

In the analyses of solitary mammals such as lynx and bear, the majority of examples referred to the relationship between the female and her young. Consequently the feminine gender prevailed.

The horse was the "highest" animal included into this comparative analysis. I have retrieved only five articles concerning horse species. The gender assignment in horses has been connected with description of breeds and behaviour. The majority of them have names. Stallions have prevailed.

\section{Conclusion}

To conclude, all the species yielded a high number of masculine and feminine gender markers in both subcorpora.

The main contexts and situations where observing strict gender distinctions proved important were similar in both sources: 
- The description of mating and courtship processes.

- The description of motherhood and parental care.

- The close relationship between the researchers and the animal in long-term studies.

- The animals analysed are identified through markings.

Although the biological sex plays the dominant role in assigning gender to animals, the sociological aspect in both study materials is also important.

\section{References}

Brinton, Laurel J. (2000) The Structure of Modern English. Amsterdam and Philadelphia: Benjamins.

Corbett, Greville (1991) Gender. Cambridge: Cambridge University Press.

Corbett, Greville and Norman M. Fraser (2000) 'Default genders.' In: Unterbeck, Barbara and Matti Rissanen (eds.) Gender in Grammar and Cognition. Berlin: de Gruyter, 55-97.

Crystal, David (1995) The Cambridge Encyclopedia of the English Language. Cambridge: Cambridge University Press.

Erades, P.A. (1956) 'Contributions to Modern English Syntax: A Note on Gender.' Moderna Sprak 15. Stockholm, 2-11.

Mackay, Donald G. and Toshi Konishi (1980) 'Personification and the Pronoun Problem.' Women 's Studies International Quarterly 3, 149-163.

Marcoux, Denise R. (1973) 'Deviation in English Gender.' American Speech 48, 98-107.

Morris, Lori (1991) Gender in Modern English: The System and its Uses. Ph.D. thesis, Quebec: Université Laval.

Prčíková, Mariana (1999) 'Gender and Animals.' Acta Facultatis Universitatis Prešoviensis. Společenskovedný zošit 18. Prešov, 85-141.

Vachek, Josef (1964) 'Notes on Gender in Modern English.' Brno Studies in English 12, 189-194.

Wagner, Susanne (2000) 'Depends How Long you Want for it to Take. For/to Clauses in Presentday Spoken British English.' Arbeiten aus Anglistik und Amerikanistik 25, 191-211.

Wagner, Susanne (2003) Gender in English Pronouns - Myth and Reality. Ph.D. thesis, Universität Freiburg.

Wagner, Susanne (2004) 'Gendered Pronouns in English Dialects - A typological Perspective.' In: Kortmann, Bernd (ed.) Dialectology Meets Typology. Berlin and New York: de Gruyter, 479-496.

Ludmila Zemková is an assistant professor in the Department of English at the Faculty of Education, University of South Bohemia, České Budějovice. She teaches Introduction to the Study of Language and English Morphology. In 2009 she finished her postgraduate studies in English language at the Faculty of Arts, Masaryk University in Brno. Her recent publications focus on the study of the linguistic concept of gender and gender in present-day English.

Address: Mgr. Ludmila Zemková, Ph.D., Department of English, Faculty of Education, University of South Bohemia, Jeronýmova 10, 37115 České Budějovice, Czech Republic. [email: zemkova@ pf.jcu.cz] 